\title{
ACTIVE PARAMETRIC IDENTIFICATION OF GAUSSIAN LINEAR DISCRETE SYSTEM BASED ON EXPERIMENT DESIGN
}

V.M. Chubich, Novosibirsk State Technical University, Novosibirsk, Russian

Federation, chubich@ami.nstu.ru, O.S. Chernikova, Novosibirsk State Technical University, Novosibirsk, Russian Federation, chernikova@corp.nstu.ru, E.A. Beriket, Novosibirsk State Technical University, Novosibirsk, Russian Federation, beriket.e.a@gmail.com

The application of methods of theory of experiment design for the identification of dynamic systems allows the researcher to gain more qualitative mathematical model compared with the traditional methods of passive identification. In this paper, the authors summarize results and offer the algorithms of active identification of the Gaussian linear discrete systems based on the design inputs and initial states. We consider Gaussian linear discrete systems described by state space models, under the assumption that unknown parameters are included in the matrices of the state, control, disturbance, measurement, covariance matrices of system noise and measurement. The original software for active identification of Gaussian linear discrete systems based on the design inputs and initial states are developed. Parameter estimation is carried out using the maximum likelihood method involving the direct and dual procedures for synthesizing A- and D- optimal experiment design. The example of the model structure for the control system of submarine shows the effectiveness and appropriateness of procedures for active parametric identification.

Keywords: parameter estimation; maximum likelihood method; Kalman filter; experiment design; (Fisher) information matrix.

\section{Introduction}

Mathematical modelling is one of intensively developing scientific directions. Identification is an important element and the most difficult stage of the solution of the applied problem in various industries, transport, at calculation of systems of automatic control. In this regard development of software for parametrical identification models becomes especially important for fundamental science and practice.

In terms of way of behavior present methods of identification can be divided into passive and active. In passive identification of dynamic systems only real operating signals and initial state are used in the modes of not disturbed operation [1-4].

On the contrary, active identification assumes violation of technological mode and uses some special synthesized designs [5-9]. So, in a frequency method of parameter estimation of linear stationary models $[10,11]$ the signal represents the sum of harmonics which number doesn't exceed dimension of space. In this work optimal plan of experiment is searched during the extreme problem solution for some preliminary chosen functional of information (or covariance) vector-matrix of parameters to be estimated. The difficulties connected with necessity of violation of a technological mode are provided by increase of efficiency and correctness of research. Methods of active identification give to the 
experimenter considerably greater possibilities in the design of qualitative model in comparison with methods of passive identification. These possibilities are caused by the ideology of the active identification based on a combination of traditional parameter estimation techniques with the concept of experiment design.

Works [12-15] are devoted to theoretical and applied aspects of the problem of active parametric identification of stochastic linear discrete systems based on design of input signals and initial states.

The authors tried to generalize the results obtained in these papers and constructed new algorithms connected with the simultaneous design inputs and initial states.

The questions of estimating the unknown parameters that we considered, together with the developed methods for designing experiments, enable us to achieve a general understanding of active identification.

\section{Problem Definition}

Consider the following model of controllable, observable and identifiable stochastic linear discrete system in the state space:

$$
\begin{gathered}
x\left(t_{k+1}\right)=F\left(t_{k}\right) x\left(t_{k}\right)+\Psi\left(t_{k}\right) u\left(t_{k}\right)+\Gamma\left(t_{k}\right) w\left(t_{k}\right), \\
y\left(t_{k+1}\right)=H\left(t_{k+1}\right) x\left(t_{k+1}\right)+v\left(t_{k+1}\right), k=0,1, \ldots, N-1 .
\end{gathered}
$$

Here $x\left(t_{k}\right)$ is the state $n$-vector; $u\left(t_{k}\right)$ is the deterministic control (input) $r$-vector; $w\left(t_{k}\right)$ is the process noise $p$-vector; $y\left(t_{k+1}\right)$ is the measurement (output) $m$-vector; $v\left(t_{k+1}\right)$ is the measurement noise $m$-vector.

Suppose that

- the random vectors $w\left(t_{k}\right)$ and $v\left(t_{k+1}\right)$ form stationary white Gaussian sequences with

$$
\begin{gathered}
E\left[w\left(t_{k}\right)\right]=0, E\left[w\left(t_{k}\right) w^{T}\left(t_{i}\right)\right]=Q \delta_{k i}, \\
E\left[v\left(t_{k+1}\right)\right]=0, E\left[v\left(t_{k+1}\right) v^{T}\left(t_{i+1}\right)\right]=R \delta_{k i}, \\
E\left[\nu\left(t_{k}\right) w^{T}\left(t_{i}\right)\right]=0, k, i=0,1, \ldots, N-1
\end{gathered}
$$

$\left(E[\cdot]\right.$ denotes the mathematical expectation, $\delta_{k i}$ is the Kronecker symbol);

- the initial state $x\left(t_{0}\right)$ is normally distributed with parameters

$$
E\left[x\left(t_{0}\right)\right]=\bar{x}\left(t_{0}\right), E\left\{\left[x\left(t_{0}\right)-\bar{x}\left(t_{0}\right)\right]\left[x\left(t_{0}\right)-\bar{x}\left(t_{0}\right)\right]^{T}\right\}=P\left(t_{0}\right)
$$

and is uncorrelated with $w\left(t_{k}\right)$ and $v\left(t_{k+1}\right)$ for all values of $k$;

- matrices $F\left(t_{k}\right), \Psi\left(t_{k}\right), \Gamma\left(t_{k}\right), H\left(t_{k+1}\right), Q, R$ depend on unknown parameters $\Theta=\left(\theta_{1}, \theta_{2}, \ldots, \theta_{s}\right) \in \Omega_{\Theta}$.

For the mathematical model (1), (2) taking the listed a priori assumptions into account, we need to develop an active parametric identification procedure based on optimal design of the input signals and initial states and study its efficiency and reasonability of application. In such mathematical statement this problem is considered and solved for the first time. 


\section{Procedure of Active Parametric Identification}

Procedure of active parametric identification of systems with preliminary chosen model structure assumes performance of following stages: calculation of parameters estimates with use of measuring data corresponding to some experiment design (stage 1, fig. 1); synthesis of experiment design based on the received estimates and chosen criterion optimality (stage 2, fig. 1) and recalculation of estimates of unknown parameters on the measuring data corresponding to the optimal design (stage 3, fig. 1).

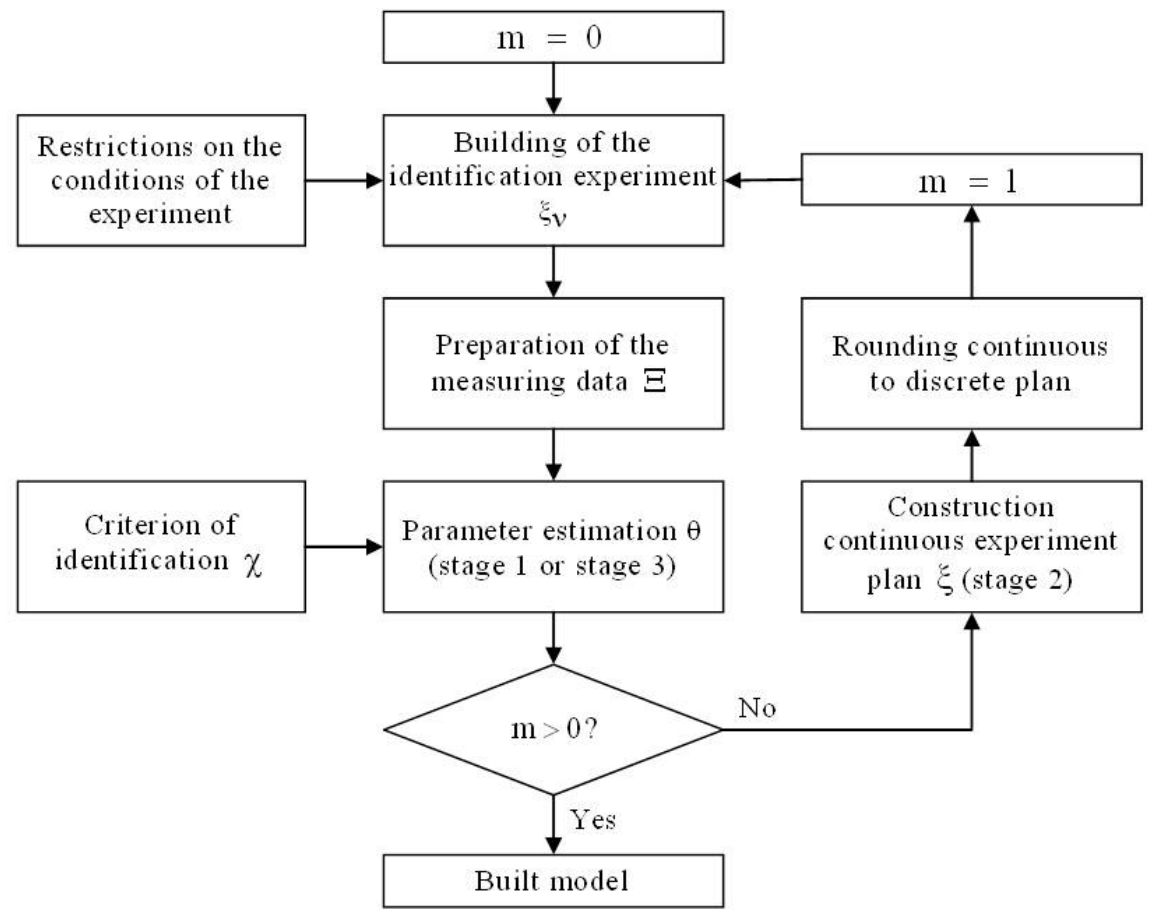

Fig 1. Scheme of active parametric identification

We will give more detailed description of stages of active parametric identification for model (1), (2) on the basis of design of the input signals and initial states.

Stage 1. Estimation of unknown parameters of mathematical model is carried out according to observation data using the criterion of identification $\chi$. Gathering of numerical data occurs during the identification experiments which are carried out under some design $\xi_{\nu}$.

Assume that experimenter can make $\nu$ system starts. He gives signal $U_{1}$ on the input of the system with initial state $\bar{x}^{1}\left(t_{0}\right)$ for $k_{1}$ times, signal $U_{2}$ with initial state $\bar{x}^{2}\left(t_{0}\right)$ for $k_{2}$ times etc., at last, signal $U_{q}$ with initial state $\bar{x}^{q}\left(t_{0}\right)$ for $k_{q}$ times. In this case discrete normalized experiment design $\xi_{\nu}\left(\sum_{i=1}^{q} k_{i}=\nu\right)$ is

$$
\xi_{\nu}=\left\{\begin{array}{c}
\alpha^{1}, \alpha^{2}, \ldots, \alpha^{q} \\
\frac{k_{1}}{\nu}, \frac{k_{2}}{\nu}, \ldots, \frac{k_{q}}{\nu}
\end{array}\right\}, \alpha^{i} \in \Omega_{\alpha}, i=1,2, \ldots, q,
$$

where the point of design spectrum $\alpha$ has the following structure:

$$
\alpha=\left[U^{T} ; \bar{x}^{T}\left(t_{0}\right)\right]=\left[u^{T}\left(t_{0}\right), u^{T}\left(t_{1}\right), \ldots, u^{T}\left(t_{N-1}\right) ; \bar{x}^{T}\left(t_{0}\right)\right]
$$


and restrictions on the conditions of carrying out experiment are defined by the bounded set

$$
\Omega_{\alpha}=\Omega_{U} \times \Omega_{\bar{x}\left(t_{0}\right)} \subset R_{N r+n} .
$$

Designate through $Y_{i, j}^{T}=\left[\left(y^{i, j}\left(t_{1}\right)\right)^{T},\left(y^{i, j}\left(t_{2}\right)\right)^{T}, \ldots,\left(y^{i, j}\left(t_{N}\right)\right)^{T}\right]$ the $j$-th output realization $\left(j=1,2, \ldots, k_{i}\right)$, corresponding to input signal $U_{i}$ with initial state $\bar{x}^{i}\left(t_{0}\right)$. Then as a result of carrying out an identification experiment for design $\xi_{\nu}$ the following set will be generated

$$
\Xi=\left\{\left(\alpha^{i}, Y_{i, j}\right), j=1,2, \ldots, k_{i}, i=1,2, \ldots, q\right\} .
$$

The apriori assumptions stated in section II allow to use maximum likelihood (ML) method for parameter estimation. It's known that when performing certain conditions (regularity conditions), ML estimates possess such properties, important for practice, as asymptotic unbiasedness, consistency, asymptotic efficiency and asymptotic normality. According to this method it is necessary to find such values of parameters $\widehat{\Theta}$ for which

$$
\widehat{\Theta}=\arg \min _{\Theta \in \Omega_{\Theta}} \chi(\Theta ; \Xi)=\arg \min _{\Theta \in \Omega_{\Theta}}[-\ln L(\Theta ; \Xi)]
$$

and (see, for example, $[12,14,15])$

$\chi(\Theta ; \Xi)=\frac{N m \nu}{2} \ln 2 \pi+\frac{1}{2} \sum_{i=1}^{q} \sum_{j=1}^{k_{i}} \sum_{k=0}^{N-1}\left[\varepsilon^{i, j}\left(t_{k+1}\right)\right]^{T} B^{-1}\left(t_{k+1}\right)\left[\varepsilon^{i, j}\left(t_{k+1}\right)\right]+\frac{\nu}{2} \sum_{k=0}^{N-1} \ln \operatorname{det} B\left(t_{k+1}\right)$,

where $\varepsilon^{i, j}\left(t_{k+1}\right)$ and $B\left(t_{k+1}\right)$ are defined according to corresponding recursive equations of discrete Kalman filter:

$$
\begin{gathered}
\widehat{x}^{i, j}\left(t_{k+1} \mid t_{k}\right)=F\left(t_{k}\right) \widehat{x}^{i, j}\left(t_{k} \mid t_{k}\right)+\Psi\left(t_{k}\right) u^{i}\left(t_{k}\right) ; \\
P\left(t_{k+1} \mid t_{k}\right)=F\left(t_{k}\right) P\left(t_{k} \mid t_{k}\right) F^{T}\left(t_{k}\right)+\Gamma\left(t_{k}\right) Q \Gamma^{T}\left(t_{k}\right) ; \\
\widehat{y}^{i, j}\left(t_{k+1} \mid t_{k}\right)=H\left(t_{k+1}\right) \widehat{x}^{i, j}\left(t_{k+1} \mid t_{k}\right) ; \\
\varepsilon^{i, j}\left(t_{k+1}\right)=y^{i, j}\left(t_{k+1}\right)-\widehat{y}^{i, j}\left(t_{k+1} \mid t_{k}\right) ; \\
B\left(t_{k+1}\right)=H\left(t_{k+1}\right) P\left(t_{k+1} \mid t_{k}\right) H^{T}\left(t_{k+1}\right)+R ; \\
K\left(t_{k+1}\right)=P\left(t_{k+1} \mid t_{k}\right) H^{T}\left(t_{k+1}\right) B^{-1}\left(t_{k+1}\right) ; \\
\widehat{x}^{i, j}\left(t_{k+1} \mid t_{k+1}\right)=\widehat{x}^{i, j}\left(t_{k+1} \mid t_{k}\right)+K\left(t_{k+1}\right) \varepsilon^{i, j}\left(t_{k+1}\right) ; \\
P\left(t_{k+1} \mid t_{k+1}\right)=\left[I-K\left(t_{k+1}\right) H\left(t_{k+1}\right)\right] P\left(t_{k+1} \mid t_{k}\right) ;
\end{gathered}
$$

for $k=0,1, \ldots, N-1, i=1,2, \ldots, k_{i}, j=1,2, \ldots, q$ with initial conditions $\widehat{x}^{i, j}\left(t_{0} \mid t_{0}\right)=\bar{x}\left(t_{0}\right)$, $P\left(t_{0} \mid t_{0}\right)=P\left(t_{0}\right)$.

Stage 2. Under continuous normalized design $\xi$ we will understand the collection

$$
\xi=\left\{\begin{array}{c}
\alpha^{1}, \alpha^{2}, \ldots, \alpha^{q} \\
p_{1}, p_{2}, \ldots, p_{q}
\end{array}\right\}, p_{i} \geq 0, \sum_{i=1}^{q} p_{i}=1, \alpha^{i} \in \Omega_{\alpha}, i=1,2, \ldots, q .
$$


For design (5) normalized information matrix $M(\xi)$ is defined by

$$
M(\xi)=\sum_{i=1}^{q} p_{i} M\left(\alpha^{i} ; \theta\right),
$$

where (Fisher) information matrices for one-point designs $M\left(\alpha^{i} ; \theta\right)$ depend on unknown parameters (this fact allows us to speak further only about locally optimal design) and are calculated in accordance with the algorithm from [16].

The quality of parameter estimation can be improved by construction of experiment design which optimizes some convex functional $X$ of information matrix $M(\xi)$, i.e. we should solve the extreme problem

$$
\xi^{*}=\arg \min _{\xi \in \Omega_{\xi}} X[M(\xi)]
$$

We will use criterion of D- and A- optimality for which, respectively, $X[M(\xi)]=$ $-\ln \operatorname{det} M(\xi)$ and $X[M(\xi)]=-S p M^{-1}(\xi)$. Solving the problem of design experiments, we act in a certain way on lower bound in the Rao-Cramer inequality: for a D-optimal design we minimize the volume, and for an A-optimal design we minimize the sum of the squares of axis lengths of the concentration ellipsoid of the estimates for the parameters.

We can solve the optimization problem of finding the minimum of $(7)$ using the general numerical methods for finding extrema. The two approaches are possible.

The first (direct) approach is to seek the minimum of the functional $X[M(\xi)]$ taking into account that design spectrum (5) consist of $q=\frac{s(s+1)}{2}+1$ points. Another approach (it is called dual) to solving the optimal problem (7) is based on the equivalence theorem [5, 14]. In this case the problem under the study is no longer a convex programming problem, but the size of the parameter vector being varied can turn out substantially smaller than in the direct approach.

Applying of the gradients in the direct or dual procedures leads to the significant improve ment of the speed of problem solving. It is impossible without calculation of derivatives of (Fisher) information matrix by the components of input signal and initial state. In this case, the gradient of the optimality criterion for points of the spectrum plan has the following structure:

$$
\frac{\partial X[M(\xi)]}{\partial \alpha^{i}}=\left[\begin{array}{c}
\frac{\partial X[M(\xi)]}{\left.\left.\partial U_{i}\right)\right]} \\
\left.\frac{\partial X[M(\xi)]}{\partial \bar{x}^{i}\left(t_{0}\right)}\right)
\end{array}\right]=\left[\begin{array}{c}
\frac{\partial X[M(\xi)]}{\partial u^{i}\left(t_{0}\right)} \\
\cdots \\
\frac{\partial X[M(\xi)]}{\partial u^{i}\left(t_{N}-1\right)} \\
\frac{\partial X[M(\xi)]}{\partial \bar{x}^{i}\left(t_{0}\right)}
\end{array}\right], i=1,2, \ldots, q .
$$

The algorithms for the calculation of gradients $\frac{\partial X[M(\xi)]}{\partial u^{i}\left(t_{k}\right)}$ and $\frac{\partial X[M(\xi)]}{\partial \bar{x}^{i}\left(t_{0}\right)}$ for $\mathrm{D}$-optimality and $\mathrm{A}$-optimality criterions are given in $[17,18]$.

Stage 3. Recalculation of estimates of unknown parameters on the measuring data corresponding to the optimal design.

Practical application of the constructed continuous optimum design is complicated because the weights $p_{i}^{*}$ are, generally speaking, arbitrary real numbers in the range from zero to one. It is easy to notice that in case of given number of possible starts of the system $\nu$ values $k_{i}^{*}=\nu p_{i}^{*}$ can be noninteger numbers. Carrying out of experiment demands 
a rounding off of values $k_{i}^{*}$ to integers. It is obvious that the design received as a result of such rounding off will differ from the optimum continuous design. An approach to the optimum continuous design is better when the number of possible starts is larger.

The possible algorithm of "rounding off" of the continuous design to the discrete design is given in [19].

Next, we make a discrete design

$$
\xi_{\nu}^{*}=\left\{\begin{array}{c}
\alpha_{*}^{1}, \alpha_{*}^{2}, \ldots, \alpha_{*}^{q} \\
\frac{k_{1}^{*}}{\nu}, \frac{k_{2}^{*}}{\nu}, \ldots, \frac{k_{q}^{*}}{\nu}
\end{array}\right\},
$$

conduct the identification experiment and recalculate estimation of unknown parameters.

\section{Experimental Results}

Consider the following mathematical model of Gaussian linear discrete control systems of the submarine making the movement with an angular speed $\omega$ and longitudinal speed of the course in the vertical plane at an angle of trim $\mu$, taking into account a deviation of fodder horizontal wheels at an angle $\delta$ from neutral position (see fig. 2) [20]:

$$
\begin{aligned}
& \left(\begin{array}{c}
\dot{\omega(t)} \\
\dot{\mu(t)} \\
\dot{\delta(t)}
\end{array}\right)=\left(\begin{array}{ccc}
\theta_{1} & \theta_{2} & \theta_{3} \\
1 & 0 & 0 \\
0 & 0 & 0
\end{array}\right)\left(\begin{array}{l}
\omega(t) \\
\mu(t) \\
\delta(t)
\end{array}\right)+\left(\begin{array}{l}
0 \\
0 \\
1
\end{array}\right) u(t)+\left(\begin{array}{c}
h \\
0 \\
0.01 h
\end{array}\right) w(t), \\
& y\left(t_{k+1}\right)=\mu\left(t_{k+1}\right)+v\left(t_{k+1}\right), k=0,1, \ldots, N-1 .
\end{aligned}
$$

The discrete model of a state (8) with discretization step $\Delta T=0,5$ is given by

$$
\left(\begin{array}{l}
\omega\left(t_{k+1}\right) \\
\psi\left(t_{k+1}\right) \\
\delta\left(t_{k+1}\right)
\end{array}\right)=F\left(\begin{array}{l}
\omega\left(t_{k}\right) \\
\mu\left(t_{k}\right) \\
\delta\left(t_{k}\right)
\end{array}\right)+\Psi u\left(t_{k}\right)+\Gamma w\left(t_{k}\right)
$$

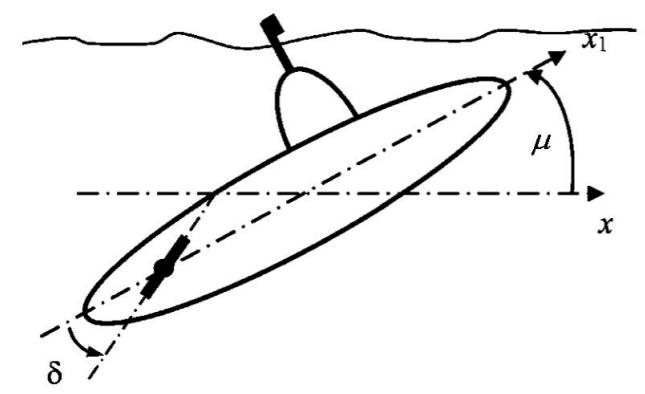

Fig 2. The submarine in the vertical plane

$$
F=\left[\begin{array}{ccc}
\frac{\sqrt{\theta_{1}^{2}+4 \theta_{2}} * A-\theta_{1} * B}{2 \sqrt{\theta_{1}^{2}+4 \theta_{2}}} & -\frac{\theta_{2} * B}{\sqrt{\theta_{1}^{2}+4 \theta_{2}}} & -\frac{\theta_{3} * B}{\sqrt{\theta_{1}^{2}+4 \theta_{2}}} \\
\frac{-B}{\sqrt{\theta_{1}^{2}+4 \theta_{2}}} & \frac{\sqrt{\theta_{1}^{2}+4 \theta_{2}} * A+\theta_{1} * B}{2 \sqrt{\theta_{1}^{2}+4 \theta_{2}}} & \frac{\theta_{3} \sqrt{\theta_{1}^{2}+4 \theta_{2} *(A-2)+\theta_{1} \theta_{3} * B}}{2 \sqrt{\theta_{1}^{2}+4 \theta_{2}}} \\
0 & 0 & 1
\end{array}\right] ;
$$




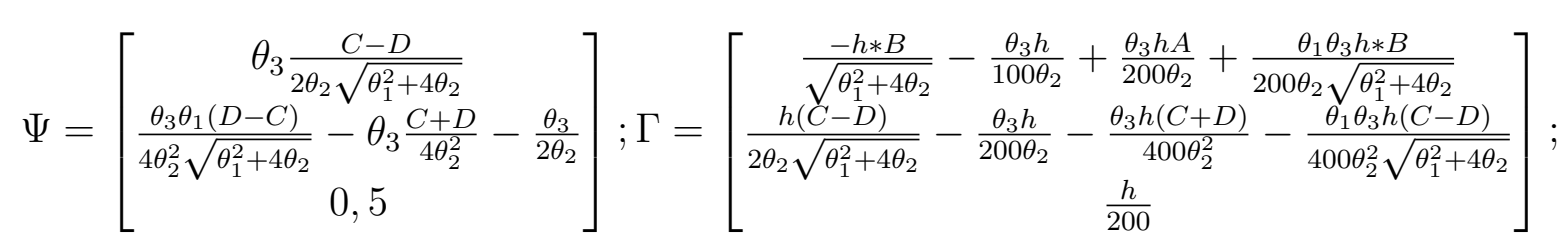

$$
\begin{aligned}
& A=\left[e^{0,25\left(\theta_{1}-\sqrt{\theta_{1}^{2}+4 \theta_{2}}\right)}+e^{0,25\left(\theta_{1}+\sqrt{\theta_{1}^{2}+4 \theta_{2}}\right)}\right] ; B=\left[e^{0,25\left(\theta_{1}-\sqrt{\theta_{1}^{2}+4 \theta_{2}}\right)}-e^{0,25\left(\theta_{1}+\sqrt{\theta_{1}^{2}+4 \theta_{2}}\right)}\right] ; \\
& C=\left(\theta_{1}+\sqrt{\theta_{1}^{2}+4 \theta_{2}}\right)\left(e^{0,25\left(\theta_{1}-\sqrt{\theta_{1}^{2}+4 \theta_{2}}\right)}-1\right) ; \\
& D=\left(\theta_{1}-\sqrt{\theta_{1}^{2}+4 \theta_{2}}\right)\left(e^{0,25\left(\theta_{1}+\sqrt{\theta_{1}^{2}+4 \theta_{2}}\right)}-1\right) \text {. }
\end{aligned}
$$

Assume that $-0,16 \leq \theta_{1} \leq-0,06,-0,006 \leq \theta_{2} \leq-0,001,-0,006 \leq \theta_{3} \leq-0,001$, $N=40$ and all listed a priori assumptions are satisfied so that

$$
\begin{gathered}
E\left[w\left(t_{k}\right) w\left(t_{i}\right)\right]=5,5 \delta_{k i}=Q \delta_{k i} ; \\
E\left[v\left(t_{k}\right) v\left(t_{i}\right)\right]=0,5 \delta_{k i}=R \delta_{k i} ; E\left[x\left(t_{0}\right)\right]=\left(\begin{array}{l}
0 \\
4 \\
0
\end{array}\right)=\bar{x}\left(t_{0}\right) ; \\
E\left\{\left[x\left(t_{0}\right)-\bar{x}\left(t_{0}\right)\right]\left[x\left(t_{0}\right)-\bar{x}\left(t_{0}\right)\right]^{T}\right\}=\left(\begin{array}{ccc}
0,01 & 0 & 0 \\
0 & 0,01 & 0 \\
0 & 0 & 0,01
\end{array}\right)=P\left(t_{0}\right) .
\end{gathered}
$$

Choose the design area $\Omega_{\alpha}=\Omega_{U} \times \Omega_{\bar{x}\left(t_{0}\right)}$, where

$$
\begin{gathered}
\Omega_{U}=\left\{-6 \leq u\left(t_{k}\right) \leq 6, k=0,1, \ldots, N-1\right\}, \\
\Omega_{\bar{x}\left(t_{0}\right)}=\left\{\left(\begin{array}{l}
0 \\
0 \\
0
\end{array}\right) \leq \bar{x}\left(t_{0}\right) \leq\left(\begin{array}{l}
1 \\
4 \\
4
\end{array}\right)\right\},
\end{gathered}
$$

and D-optimality criterion.

In order to weaken the dependence of estimation results on measurement data we will make five independent starts of system, i.e. $(\nu=5)$ and then we will average the received estimates of unknown parameters. Realizations of output signal we get by the computer modelling with true values of parameters $\theta_{1}^{*}=-0,1253, \theta_{2}^{*}=-0,004631, \theta_{3}^{*}=-0,002198$.

The quality of identification in the parameter space and response space will be judged by values of factors $\delta_{\theta}, \delta_{\theta}^{*}$ and $\delta_{Y}, \delta_{Y}^{*}$ accordingly. These factors are calculated by following formulas:

$$
\begin{gathered}
\delta_{\theta}=\frac{\left\|\theta^{*}-\hat{\theta}\right\|}{\left\|\theta^{*}\right\|}=\sqrt{\frac{\sum_{i=1}^{s}\left(\theta_{i}^{*}-\hat{\theta}_{i}\right)^{2}}{\sum_{i=1}^{s}\left(\theta_{i}^{*}\right)^{2}}} ; \delta_{\theta}^{*}=\frac{\left\|\theta^{*}-\hat{\theta}^{*}\right\|}{\left\|\theta^{*}\right\|}=\sqrt{\frac{\sum_{i=1}^{s}\left(\theta_{i}^{*}-\hat{\theta}_{i}^{*}\right)^{2}}{\sum_{i=1}^{s}\left(\theta_{i}^{*}\right)^{2}} ;} \\
\delta_{Y}=\sqrt{\frac{\sum_{i=1}^{q} \sum_{j=1}^{k_{i}} \sum_{k=0}^{N-1}\left(y^{i, j}\left(t_{k+1}\right)-\hat{y}^{i, j}\left(t_{k+1} \mid t_{k}\right)\right)^{2}}{\sum_{i=1}^{q} \sum_{j=1}^{k_{i}} \sum_{k=0}^{N-1}\left(y^{i, j}\left(t_{k+1}\right)\right)^{2}}} ; \delta_{Y}^{*}=\sqrt{\frac{\sum_{i=1}^{q} \sum_{j=1}^{k_{i}} \sum_{k=0}^{N-1}\left(y^{i, j}\left(t_{k+1}\right)-\hat{y}_{*}^{i, j}\left(t_{k+1} \mid t_{k}\right)\right)^{2}}{\sum_{i=1}^{q} \sum_{j=1}^{k_{i}} \sum_{k=0}^{N-1}\left(y^{i, j}\left(t_{k+1}\right)\right)^{2}}},
\end{gathered}
$$


where $\theta^{*}$ are true values of parameters; $\hat{\theta}$ are estimates of unknown parameters values based on the initial experiment design; $\hat{\theta}^{*}$ are estimates of unknown parameters values based on the synthesized input signal and (or) initial states; $\hat{y}^{i j}\left(t_{k+1} \mid t_{k}\right)$ and $\hat{y}_{*}^{i j}\left(t_{k+1} \mid t_{k}\right)$ are calculated on using the equations of Kallman filter at $\hat{\theta}$ and $\hat{\theta}^{*}$ respectively.

Results of the active parametric identification procedure based on D-optimal design of input signals and (or) initial state are presented in Table.

Table

Result of active identification procedures based on design of input signals and (or) initial state

\begin{tabular}{|c|c|}
\hline Discrete experiment design & $\begin{array}{l}\text { Values of parameters estimates } \\
\text { and errors of estimation }\end{array}$ \\
\hline 1 & 2 \\
\hline $\begin{array}{c}\text { Initial design } \\
\xi_{\nu}=\left\{\begin{array}{c}\alpha^{1} \\
\frac{k_{1}}{\nu}=1\end{array}\right\}\end{array}$ & $\begin{array}{l}\hat{\theta}_{1}=-0,1600 \\
\hat{\theta}_{2}=-0,0059 \\
\hat{\theta}_{3}=-0,0015\end{array}$ \\
\hline $\begin{array}{l}\alpha^{1}=\left[U^{T} ; \bar{x}^{T}\left(t_{0}\right)\right], \quad \text { input signal } U^{T}= \\
{\left[(6,-6)_{2},-6_{4}, 6_{3},-6,6,-6_{2},-6,6,-6_{2}, 6_{2},-6,6_{3},\right.} \\
\left.-6,6,-6_{3},(6,-6)_{3},-6,6,-6_{3}\right], \quad \text { initial state } \\
\bar{x}\left(t_{0}\right)=(0,4,0)^{T} .\end{array}$ & $\begin{array}{l}\delta_{\theta}=0,2770 \\
\delta_{Y}=0,1488\end{array}$ \\
\hline $\begin{array}{l}\text { Design of initial states } \\
\xi_{\nu}^{*}=\left\{\begin{array}{cc}\alpha^{1} & \alpha^{2} \\
\frac{k_{1}}{\nu}=\frac{2}{5} & \frac{k_{2}}{\nu}=\frac{3}{5}\end{array}\right\}\end{array}$ & $\begin{array}{l}\hat{\theta}_{1}=-0,1372 \\
\hat{\theta}_{2}=-0,0052 \\
\hat{\theta}_{2}=-0,0019\end{array}$ \\
\hline $\begin{array}{l}\alpha^{i}=\left[U^{T} ;\left(\bar{x}^{i}\left(t_{0}\right)^{T}\right)\right], \text { input signal } U^{T}= \\
{\left[(6,-6)_{2},-6_{4}, 6_{3},-6,6,-6_{2},-6,6,-6_{2}, 6_{2},-6,6_{3},\right.} \\
\left.-6,6,-6_{3},(6,-6)_{3},-6,6,-6_{3}\right], \quad \text { initial states } \\
\bar{x}_{*}^{1}\left(t_{0}\right)=(0,4,0)^{T}, \bar{x}_{*}^{2}\left(t_{0}\right)=(1,4,0)^{T} .\end{array}$ & $\begin{array}{l}\delta_{\theta}=0,0953 \\
\delta_{Y}=0,1049\end{array}$ \\
\hline $\begin{array}{l}\text { Design of input signals } \\
\xi_{\nu}^{*}=\left\{\begin{array}{c}\alpha^{1} \quad \alpha^{2} \quad \alpha^{3} \quad \alpha^{4} \\
\frac{k_{1}^{*}}{\nu}=\frac{1}{5} \frac{k_{2}^{*}}{\nu}=\frac{2}{5} \frac{k_{3}^{*}}{\nu}=\frac{1}{5} \frac{k_{4}^{*}}{\nu}=\frac{1}{5}\end{array}\right\}\end{array}$ & $\begin{array}{l}\hat{\theta}_{1}=-0,1301 \\
\hat{\theta}_{2}=-0,0049 \\
\hat{\theta}_{3}=-0,0019\end{array}$ \\
\hline $\begin{array}{l}\alpha^{i}=\left[\left(U_{*}^{i}\right)^{T} ; \bar{x}_{*}^{T}\left(t_{0}\right)\right], \text { input signals }\left(U_{*}^{1}\right)^{T}=\left[6_{40}\right]^{1}, \\
\left(U_{*}^{2}\right)^{T}=\left[6_{15},-6_{25}\right],\left(U_{*}^{3}\right)^{T}=\left[6_{40}\right],\left(U_{*}^{4}\right)^{T}= \\
{\left[6_{20},-6_{20}\right], \text { initial state } \bar{x}_{*}\left(t_{0}\right)=(0,4,0)^{T} .}\end{array}$ & $\begin{array}{l}\delta_{\theta}=0,0380 \\
\delta_{Y}=0,0908\end{array}$ \\
\hline $\begin{array}{c}\text { Design input signals and initial states } \\
\xi_{\nu}^{*}=\left\{\begin{array}{c}\alpha^{1} \alpha^{2} \alpha^{3} \alpha^{4} \\
\frac{k_{1}^{*}}{\nu}=\frac{2}{5} \frac{k_{2}^{*}}{\nu}=\frac{1}{5} \frac{k_{3}^{*}}{\nu}=\frac{1}{5} \frac{k_{4}^{*}}{\nu}=\frac{1}{5}\end{array}\right\}\end{array}$ & $\begin{aligned} \hat{\theta}_{1} & =-0,1248 \\
\hat{\theta}_{2} & =-0,0042 \\
\hat{\theta}_{3} & =-0,0024\end{aligned}$ \\
\hline $\begin{array}{l}\alpha^{i}=\left[\left(U_{*}^{i}\right)^{T} ;\left(\bar{x}_{*}^{i}\left(t_{0}\right)^{T}\right)\right], \text { input signals }\left(U_{*}^{1}\right)^{T}= \\
{\left[6_{40}\right],\left(U_{*}^{2}\right)^{T}=\left[6_{24},-6_{16}\right],\left(U_{*}^{3}\right)^{T}=\left[6_{12},-6_{28}\right],} \\
\left(U_{*}^{4}\right)^{T}=\left[6_{25},-6_{15}\right], \text { initial states } \bar{x}_{*}^{1}\left(t_{0}\right)= \\
(1,4,0)^{T}, \bar{x}_{*}^{2}\left(t_{0}\right)=\bar{x}_{*}^{3}\left(t_{0}\right)=\bar{x}_{*}^{4}\left(t_{0}\right)=(1,4,4)^{T} .\end{array}$ & $\begin{array}{l}\delta_{\theta}=0,0055 \\
\delta_{Y}=0,0750\end{array}$ \\
\hline
\end{tabular}

\footnotetext{
${ }^{1}$ Record $\left[a_{k}, b_{m}, \ldots\right]$ means that the number a repeats $k$ times, number $b-m$ times.
} 
The calculations were performed using the interactive software system of the active parametric identification (APIS). APIS was developed by the authors at the Department of the theoretical and applied informatics NSTU and allows to solve problems of active parametric identification of nonlinear stochastic discrete and discrete-continuous systems based on planning of A- and D- optimal input signals using statistical and temporal linearization. Furthermore, the software system allows optimal estimation of model parameters for Gaussian linear dynamic systems based on the design of the input signals and (or) the initial states [21].

We executed five starts of system, given a pseudorandom binary signal $U$. For each start at $\theta=\theta^{*}$ we simulate data measurements using equations (8), (10) $Y=\left\{y\left(t_{1}\right), y\left(t_{2}\right), \ldots, y\left(t_{N}\right)\right\}$, write down $\hat{Y}=\left\{\hat{y}\left(t_{1} \mid t_{1}\right), \hat{y}\left(t_{2} \mid t_{2}\right), \ldots, \hat{y}\left(t_{N} \mid t_{N}\right)\right\}$, $\left.\hat{y}^{*}\left(t_{2} \mid t_{2}\right), \ldots, \hat{y}^{*}\left(t_{N} \mid t_{N}\right)\right\}, \hat{Y}^{*}=\left\{\hat{y}^{*}\left(t_{1} \mid t_{1}\right)\right\}$ in accordance with $\theta=\hat{\theta}_{c p}$ and $\theta=\hat{\theta}_{c p}^{*}$; average the results $Y_{c p}, \hat{Y}_{c p}, \hat{Y}_{c p}^{*}$, (see fig. $3-6$ ).

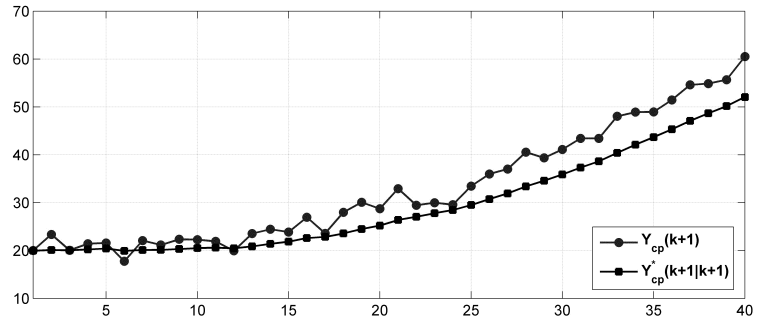

Fig 3. Graphical representation of $Y_{c p}, \hat{Y}_{c p}$ (passive identification)

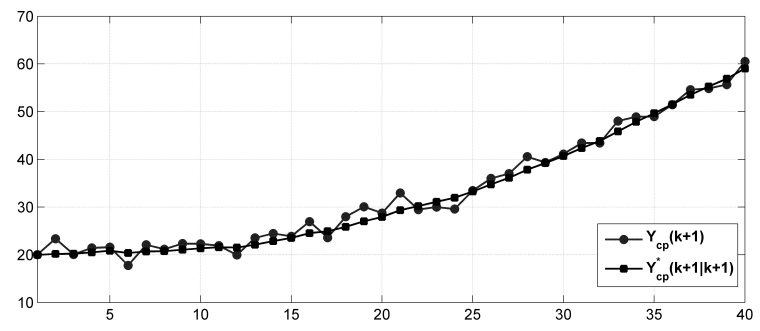

Fig 5. Graphical representation of $Y_{c p}, \hat{Y}_{c p}^{*}$ (design of the input signals)

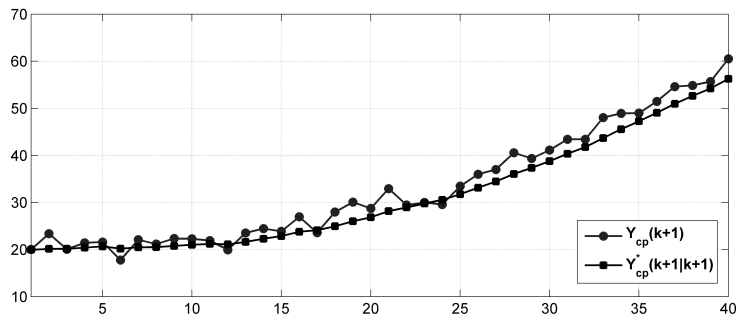

Fig 4. Graphical representation of $Y_{c p}, \hat{Y}_{c p}^{*}$ (design of the initial states)

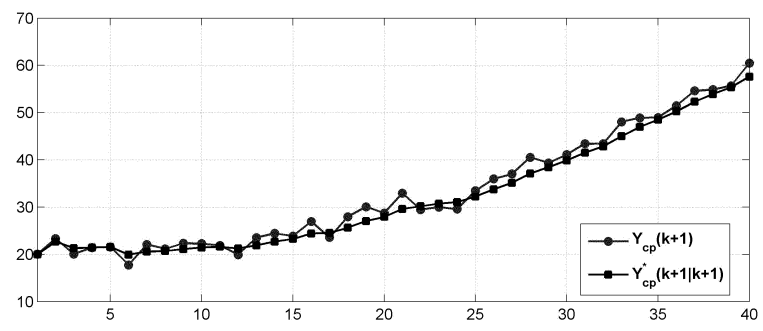

Fig 6. Graphical representation of $Y_{c p}, \hat{Y}_{c p}^{*}$ (design of the input signals and initial states)

The results presented in Table, show that design of the initial states led to better estimation only by $18,2 \%$ in the parameter space, and $4,4 \%$ in the space of responses, while design of the input signals contributed to the improvement of evaluation results only by $23,9 \%$ and $5,9 \%$, respectively. The most successful results were obtained for the case of design of the inputs and initial states (improvement by $27,2 \%$ and $7,4 \%$ ).

Thus, the authors consider that applying of the active parametric identification procedures based on optimal design of input signals and initial states is helpful and advisable. 


\section{Conclusion}

For the first time we considered and solved the problem of active parametric identification of the Gaussian linear discrete systems in the case when the unknown parameters are contained in the state and control equations as in well as the covariance matrices of the system and measurement noise. The original gradient algorithms for active identification based on optimal design of input signals and initial states were developed.

It was shown that design of the input signals and the initial states has a significant impact on the functional dependence of state variables and model parameters.

The work is executed under the auspices of the Ministry of education and science of the Russian Federation (№ 2014/138, project № 1689).

\section{References}

1. Kash'jap R.L. Postroenie dinamicheskih stohasticheskih modelej po jeksperimental'nym dannym [Construction of Dynamic Stochastic Models Based on Experimental Data]. Moscow, Nauka, 1983. 384 p.

2. L'jung L. Identifikacija sistem: Teorija pol'zovatelja [System Identification: Theory User]. Moscow, Nauka, 1991. 432 p.

3. Cypkin Ja.Z. Informacionnaja teorija identifikacii [Information Theory of Identification]. Moscow, Nauka, 1995. 336 p.

4. Walter E., Pronzato L. Identification of Parametric Models from Experimental Data. Berlin, Springer-Verlag, 1997. 413 p.

5. Mehra R.K. Optimal Input Signals for Parameter Estimation in Dynamic Dystems: Durvey and New Results. IEEE Trans. on Automat. Control, 1974, vol. 19, no. 6, pp. 753-768. DOI: 10.1109/TAC.1974.1100701

6. Krug G.K., Sosulin Ju.A., Fatuev V.A. Planirovanie jeksperimenta v zadachah identifikacii $i$ jekstrapoljacii [Planning Experiment in Problems of Identification and Extrapolation]. Moscow, Nauka, 1977. 208 p.

7. Ovcharenko V.N. Planning of Identifies Input Signals in Linear Dynamic Systems. Automation and Remote Control, 2001, vol. 62, no. 2, pp. 236-247. DOI: 10.1023/A:3A1002894223036

8. Jauberthie C., Denis-Vidal L., Coton P., Joly-Blanchard G. An Optimal Input Design Procedure. Automatica, 2006, vol. 42, pp. 881-884. DOI: 10.1016/j.automatica.2006.01.003

9. Voevoda A.A., Troshina G.V. [Using the Fisher Information Matrix when Selecting a Control Signal for Estimating the Parameters of Dynamic Models and Observation of Objects of Low Order]. Sbornik nauch. trudov NGTU [Collection of Scientific Works NSTU], 2006, no. 3 (45), pp. 19-24. (in Russian)

10. Alexandrov A.G. Finite-Frequency Method of Identification. Preprints of 10th IFAC Symposium on System Identification, 1994, vol. 2, pp. 523-527.

11. Aleksandrov A.G., Orlov Ju.F. [Finite-Frequency Identification: Dynamic Algorithm]. Problemy upravlenija [Problems of Control], 2009, no. 4, pp. 2-8. (in Russian)

12. Denisov V.I., Chubich V.M., Chernikova O.S. [Active Identification of Stochastic Linear Discrete Systems in the Time Domain]. Journal of Applied and Industrial Mathematics, 2003, vol. 6, no. 3, pp. 70-87. (in Russian) 
13. Denisov V.I., Chubich V.M., Chernikova O.S. Active Identification of Stochastic Linear Discrete Systems in the Frequency Domain. Journal of Applied and Industrial Mathematics, 2007, vol. 10, no. 1, pp. 183-200. DOI: 10.1134/S1990478909020057

14. Denisov V.I., Chubich V.M., Chernikova O.S., Bobyleva D.I. Aktivnaja parametricheskaja identifikacija stohasticheskih linejnyh sistem: monografija [Active Parametric Identification of Stochastic Linear Systems: Monograph]. Novosibirsk, NGTU, 2009. 192 p.

15. Chubich V.M., Chernikova O.S. [Optimal Parameter Estimation for Gaussian Models of Linear Discrete Systems Based on the Planning of the Initial Conditions]. Scientific Bulletin of NSTU, 2013, no. 3 (36), pp. 15-22. (in Russian)

16. Chubich V.M. [Computation the Fisher Information Matrix for the Problem of Active Parametric Identification of Stochastic Nonlinear Discrete Systems]. Scientific Bulletin of NSTU, 2009, no. 1 (34), pp. 23-40. (in Russian)

17. Chubich V.M. [Information Technology Active Parametric Identification of Quasi-Linear Discrete Systems]. Informatics and Applications, 2011, vol. 5, no. 1, pp. 46-57. (in Russian)

18. Chubich V.M. [Planning the Initial Conditions in the Problem of Active Parametric Identification of Gaussian Linear Discrete Systems]. Scientific Bulletin of NSTU, 2011, no. 1 (42), pp. 39-46. (in Russian)

19. Ermakov S.M., Zhigljavskij A.A. Matematicheskaja teorija optimal'nogo jeksperimenta [Mathematical theory of optimal experiment]. Moscow, Nauka, 1987. 320 p.

20. Veremej E.I. Linejnye sistemy s obratnoj svjaz'ju [Linear Systems with Feedback]. St. Petersburg, Lan', 2013. 448. p.

21. Chubich V.M., Chernikova O.S., Filippova E.V. [Software System Active Parametric Identification of Stochastic Dynamical Systems APIS]. XI Mezhdunarodnaja konferencija aktual'nye problemy jelektronnogo priborostroenija APJeP-2012 [XI International Conference on Actual Problems of Electronic Instrument Engineering APEIE-2012]. Novosibirsk, 2012, vol. 6, pp. 66-73. (in Russian)

Received April 24, 2015

\title{
АКТИВНАЯ ПАРАМЕТРИЧЕСКАЯ ИДЕНТИФИКАЦИЯ ГАУССОВСКИХ ЛИНЕЙНЫХ ДИСКРЕТНЫХ СИСТЕМ НА ОСНОВЕ ПЛАНИРОВАНИЯ ЭКСПЕРИМЕНТА
}

\author{
В.М. Чубич, О.С. Черникова, Е.А. Берикет
}

Применение методов теории планирования эксперимента при идентификации динамических систем позволяет исследователю получить более качественную математическую модель по сравнению с традиционными методами пассивной идентификации. 
В работе обобщаются ранее полученные авторские результаты и предлагаются алгоритмы активной параметрической идентификации гауссовских линейных дискретных систем на основе совместного планирования входных сигналов и начальных условий. Рассматриваются математические модели в пространстве состояний, в предположении, что подлежащие оцениванию параметры содержатся в матрицах состояния, управления, возмущения, измерения, в ковариационных матрицах шумов системы и измерений. Разработано программно-математическое обеспечение, позволяющее решать задачи активной параметрической идентификации с использованием метода максимального правдоподобия, а также прямой и двойственной градиентных процедур построения A- и D- оптимальных планов. На примере модельной структуры системы управления подводным аппаратом показана эффективность и целесообразность применения процедуры активной параметрической идентификации на основе совместного планирования входных сигналов и начальных условий.

Ключевые слова: оценивание параметров; метод максималъного правдоподобия; фильтр Калмана; планирование эксперимента; информачионная матрица.

\section{Литература}

1. Кашьяп, Р.Л. Построение динамических стохастических моделей по экспериментальным данным / Р.Л. Кашьяп, А.Р. Рао. - М.: Наука, 1983.

2. Льюнг, Л. Идентификация систем: Теория пользователя / Л. Льюнг. - М.: Наука, 1991.

3. Цыпкин, Я.З. Информационная теория идентификации / Я.З. Цыпкин. - М.: Наука, 1995.

4. Walter, E. Identification of Parametric Models from Experimental Data / E. Walter, L. Pronzato. - Berlin: Springer-Verlag, 1997.

5. Mehra, R.K. Optimal Input Signals for Parameter Estimation in Dynamic Systems: Survey and New Results / R.K. Mehra // IEEE Trans. on Automat. Control. - 1974. - V. 19, № 6. - P. 753-768.

6. Круг, Г.К. Планирование эксперимента в задачах идентификации и экстраполяции / Г.К. Круг, Ю.А. Сосулин, В.А. Фатуев. - М.: Наука, 1977.

7. Овчаренко, В.Н. Планирование идентифицирующих входных сигналов в линейных динамических системах / В.Н. Овчаренко // Автоматика и телемеханика. - 2001. - № 2. C. $75-87$.

8. Jauberthie, C. An Optimal Input Design Procedure / C. Jauberthie, L. Denis-Vidal, P. Coton, G. Joly-Blanchard // Automatica. - 2006. - V. 42. - P. 881-884.

9. Воевода, А.А. Использование информационной матрицы Фишера при выборе сигнала управления для оценки параметров моделей динамики и наблюдения объектов невысокого порядка / А.А. Воевода, Г.В. Трошина // Сб. науч. тр. НГТУ. - Новосибирск, 2006. - № 3 (45). - C. 19-24.

10. Alexandrov, A.G. Finite-Frequency Method of Identification / A.G. Alexandrov // Preprints of 10th IFAC Symposium on System Identification. - 1994. - V. 2 - P. 523-527.

11. Александров, А.Г. Конечно-частотная идентификация: динамический алгоритм / А.Г. Александров, Ю.Ф. Орлов // Проблемы управления. - 2009. - № 4. - С. 2-8.

12. Денисов, В.И. Активная идентификация стохастических линейных дискретных систем во временной области / В.И. Денисов, В.М. Чубич, О.С. Черникова // Сибирский журнал индустриальной математики. - 2003. - Т. 6, № 3. - С. 70-87.

13. Денисов, В.И. Активная параметрическая идентификация стохастических линейных дискретных систем в частотной области / В.И. Денисов, В.М. Чубич, О.С. Черникова // Сибирский журнал индустриальной математики. - 2007. - Т. 10, № 1. - С. 71-89. 
14. Активная параметрическая идентификация стохастических линейных систем: монография / В.И. Денисов, В.М. Чубич, О.С. Черникова, Д.И. Бобылева. - Новосибирск: Издво НГТУ, 2009.

15. Чубич, В.М. Оптимальное оценивание параметров моделей гауссовских линейных дискретных систем на основе планирования начальных условий / B.М. Чубич, О.С. Черникова // Научный вестник НГТУ. - 2013. - № 3 (16). - С. 15-22.

16. Чубич, В.М. Вычисление информационной матрицы Фишера в задаче активной параметрической идентификации стохастических нелинейных дискретных систем / В.М. Чубич // Научный вестник НГТУ. - 2009. - № 1 (34). - С. 23-40.

17. Чубич, В.М. Информационная технология активной параметрической идентификации квазилинейных дискретных систем / В.М. Чубич // Информатика и ее применение. 2011. - T. 5, № 1 (34). - С. 46-57.

18. Чубич, В.М. Планирование начальных условий в задаче активной параметрической идентификации гауссовских линейных дискретных систем / В.М. Чубич // Научный вестник НГТУ. - 2011. - № 1 (42). - С. 39-46.

19. Ермаков, С.М. Математическая теория оптимального эксперимента / С.М. Ермаков, А.А. Жиглявский. - М.: Наука, 1987.

20. Веремей, Е.И. Линейные системы с обратной связью / Е.И. Веремей. - СПб.: Лань, 2013.

21. Чубич, В.М. Программная система активной параметрической идентификации стохастических динамических систем APIS / В.М. Чубич, О.С. Черникова, Е.В. Филиппова // XI Междунар. конф. «Актуальные проблемы электронного приборостроения АПЭП$2012 \gg .-2012$. - T. 6. - C. $66-73$.

Владимир Михайлович Чубич, доктор технических наук, заведующий кафедрой, кафедра «Теоретическая и прикладная информатика», Новосибирский государственный технический университет (г. Новосибирск, Российская Федерация), chubich@ami.nstu.ru.

Оксана Сергеевна Черникова, кандидат технических наук, доцент, кафедра «Теоретическая и прикладная информатика», Новосибирский государственный технический университет (г. Новосибирск, Российская Федерация), chernikova@corp.nstu.ru.

Екатерина Александровна Берикет, магистрант факультета прикладной математики и информатики, Новосибирский государственный технический университет (г. Новосибирск, Российская Федерация), beriket.e.a@gmail.com.

Поступила в редакцию 24 апреля 2015 2. 